\title{
AN EMPIRICAL ASSESSMENT OF CUSTOMER SATISFACTION AND QUALITY OF SERVICE: COMPARING SERVQUAL AND SERVPERF
}

\section{UMA AVALIAÇÃO EMPÍRICA DA SATISAÇÃO DO CLIENTE E DA QUALIDADE DE SERVIÇO: COMPARANDO SERVQUAL E SERVPERF}

\author{
Manuel Afonso Machado ${ }^{1}$; Alexandrino Ribeiro ${ }^{2}$; Mário Basto $^{3}$ \\ ${ }^{1}$ Escola Superior de Tecnologia, Campus do IPCA \\ manuelafonsomachado@gmail.com \\ ${ }^{2}$ Escola Superior de Tecnologia, Campus do IPCA \\ aribeiro@ipca.pt \\ ${ }^{3}$ Escola Superior de Tecnologia, Campus do IPCA \\ mbasto@ipca.pt
}

\begin{abstract}
This paper assesses the validity and reliability of two instruments measuring quality of service, the SERVPERF and SERVQUAL scales, replicated in a novel cultural settings, a Portuguese energy company. To provide insights and strategies for managerial intervention, a relation between customers' satisfaction and quality of service is established. The empirical study suggests a superior convergent and predictive validity of SERVPERF scale to measure quality of service in this settings when comparing to SERVQUAL. The main differences of this study with previous ones, are that this one resorts on a confirmatory factor analysis, the validation of the instruments is performed by using the same measures suggested by their creators and extends the line of research to a novel cultural settings, a Portuguese energy company. Concerning the relationship between service quality and customers' satisfaction, all of the quality of service attributes correlate almost equally to the satisfaction ones, with a lower weight concerning tangibles.
\end{abstract}

Key-words: quality; servperf; servqual; confirmatory factor analysis; canonical correlation.

\section{Introduction}

The growth of essential public services, in general, has led both companies and the state to face new challenges in the area of quality of service, with clear concerns about the satisfaction and anticipation of customer needs, in order to deliver a high quality of service appropriate to market demands, especially for customers, even when the market is controlled. Nowadays, public opinion influences the political authorities, requiring public services to have quality, effectiveness, and efficiency. As service quality and customer satisfaction are very closely related and both are strictly related to the profit and other financial effects of the companies, they are a concern for organizations and managers. In this paper, the public service under study to assess customer satisfaction and quality of service is that provided by a Portuguese energy company, EDP. 
Power supply is a critical factor for development in all countries. In recent decades, there has been an increasing demand for energy services, particularly to meet the needs of economic growth and solve social and environmental issues. Energy plays a central role in all three dimensions of sustainable development: social dimension (the fight against poverty), economic size (security supply) and environmental dimension (environmental protection). Energy is now a basic good and many households (poor or not) spend a very substantial part of their income on fuel and electricity. However, there is also a need to use better energy technologies: "It has become clear that current patterns of energy use are environmentally unsustainable. The overwhelming reliance on fossil fuels, in particular, threatens to alter the Earth's climate to an extent that could have grave consequences for the integrity of both natural systems and vital human systems" (AHUJA, 2009, p. 2).

Hence, the importance to the environmental issue of the energy supplied and the concern of energy company managers with the quality of service provided. However, it is impossible to guarantee a permanent supply of electricity without interruptions due to the complexity of distribution networks, consisting of equipment and several thousands of kilometers of transmission and distribution. Transmission and distribution of energy are associated with an incident rate, due to exposure to actions caused by natural phenomena or physical damage (adverse weather events, equipment failures, human error, accidents involving persons, animals, or birds). All these factors can have more or less impact on the quality of service and customer satisfaction.

Customer satisfaction can be explained, in general terms, as a measure of the short-term feature of the transaction, and the quality of service, as an extensive one, over the long-term. Assessments of customer satisfaction and quality of service complement each other. Evaluating customer satisfaction after each transaction service helps to update the information concerning the ratings of the company's performance regarding quality of service. Customer satisfaction or dissatisfaction is the result of a comparison between the prior expectations that a customer has about the product or service and the posterior perception of the product or the service provided (SPRENG; OLSHAVSKY, 1993). One of the key factors of business success is how customers perceive the quality of service (COLLART, 2000). A detailed knowledge of the needs and expectations of their customers supports companies' commitment to deliver a high quality of service to their customers (HOFFMAN; BATESON, 2006). The first studies on the quality of services (GRÖNROOS, 1984; OLIVER, 1980), emphasize the necessity to establish strategies for assessment of the different service sectors and to make decisions based on customer satisfaction. Parasuraman, Zeithaml and Berry (1985) found that customers use the same criteria to reach a judging evaluation of the quality of service provided, regardless of the type of service in question. These criteria were generalized into categories called dimensions of quality, of which the original ten were subsequently reduced to 
five (PARASURAMAN; ZEITHAML; BERRY, 1988; ZEITHAML; PARASURAMAN; BERRY, 1990).

To achieve the purpose of this paper, the authors measured customer satisfaction and quality of service provided by a Portuguese electrical company, and established a relationship between customer satisfaction and quality of service, hence providing relevant information to the company that can lead to actions targeting the improvement of quality of service and therefore improving client satisfaction and loyalty. To reach this objective, satisfaction was assessed based on a questionnaire already implemented by the company, and quality of service was measured by the instruments known as SERVPERF and SERVQUAL (CRONIN; TAYLOR, 1992, 1994; PARASURAMAN; ZEITHAML; BERRY, 1985, 1988). Despite the general acceptance of the necessity to modify the original scales to adapt them to different services and cultures, in this paper the validity of the scales is assessed by using the non-modified versions of the scales.

This paper is organized as follows. First, the authors present a review of some of the literature discussing the two SERVPERF and SERVQUAL scales. Second, the authors present the objectives proposed and the methodology used, followed by the data analysis and results obtained, from which the validity of the replicated instruments SERVPERF and SERVQUAL are examined. Third, the authors study the association between customer satisfaction and the constructs measuring quality of service. Fourth, the findings and managerial implications are discussed, some limitations of the present study are examined and suggestions are made for future research.

\section{SERVPERF verSUS SERVQUAL}

The SERVPERF and SERVQUAL instruments are composed of 22 and $22+22$ items respectively, structured on a 7-point Likert scale that ranges from one to seven, grouped together in five dimensions (tangibles, reliability, responsiveness, assurance and empathy). SERVQUAL consists of two scales (perceptions and expectations) while SERVPERF relies only on perceptions. In SERVQUAL, the scores for quality of service are obtained from the difference between perceptions and expectations, assessed by a 7-point Likert scale from 'strongly disagree' to 'strongly agree'. The more negative this value, the more dissatisfied consumers are. Items on expectations apply to excellent companies, while items on the perceptions apply to the company under investigation.

SERVQUAL is a model based on the paradigm of inconsistency, whereby the evaluation of customer satisfaction can be carried out by measuring expectations and perceptions (OLIVER, 1977, 1981; WAVER; BRICKMAN, 1974; WESTBROOK; NEWMAN; TAYLOR, 1978). For Parasuraman et al $(1985,1988)$, the quality of the SERVQUAL instrument emerges from the gap between performance and expectations. As performance increases relative to expectations, quality 
increases. Hence, customers' expectations serve as the base on which they will evaluate service quality. Although the SERVQUAL instrument is a popular tool to measure quality of service, the psychometric properties are still being investigated. On the one hand, the SERVQUAL model has been designed to reliably estimate quality of service (PARASURAMAN; ZEITHAML; BERRY 1988, 1991, 1994; ZEITHAML; PARASURAMAN; BERRY, 1990). On the other hand, critics question its conceptual basis and psychometric properties (BABAKUS; BOLLER, 1992; BABAKUS, 1993; BROWN, CHURCHILL; PETER, 1993; CARMAN, 1990; CRONIN; TAYLOR, 1992; LAM; WOO, 1997), as it can occur that customers overstate their expectations due to the poor prior experience with the service provided by the company (CLOW; VORHIES, 1993). One of the major shortcomings to the model pointed out by critics of the model is that the five quality dimensions are not universal. The definitions of the dimensions and their number differ depending on the type of service industry and the model cannot be applied in all service industries (CARMAN, 1990; LADHARI, 2009; BUTTLE, 1996).

There are several studies comparing the two instruments, discussing which of the two scales is superior in measuring service quality, or which of them is more appropriate to be applied to a specific service in a given context. Mehta, Lalwani, and Han (2000) found that SERVQUAL was better for a retailing context where the service element is less important (supermarket), whereas, SERVPERF was better for a retailing context where the service element is more important (electronic goods retailer).

In defense of the SERVQUAL gap model, Parasuraman et al (1994) argue that there is significant theoretical and empirical research to support their theory (BERRY, 1990; BOLTON; DREW, 1991a, 1991b; PARASURAMAN; ZEITHAML; BERRY, 1985; ZEITHAML; PARASURAMAN; GRÖNROOS, 1984) and also insist that their work attests that SERVQUAL's convergent and discriminant validity is as good as or better than that of SERVPERF (PARASURAMAN; ZEITHAML; BERRY, 1994). Also Parasuraman et al (1994) state that the better predictive validity of the SERVPERF scale in Cronin and Taylor's work (1992), can be explained by the fact that, in SERVPERF, the dependent variable is a performance only based measure. However, they state that performance minus expectation measures have better diagnostic value (PARASURAMAN; ZEITHAML; BERRY, 1994).

The Cronbach's alpha reliability coefficients for the five SERVQUAL dimensions are similar across studies (ASUBONTENG; McCLEARY; SWAN, 1996), validating the internal reliability of each of the five dimensions. Concerning validity, the findings from most studies differ from the original study mainly with respect to SERVQUAL's discriminant and convergent validity (ASUBONTENG; McCLEARY; SWAN, 1996). The numbers of dimensions achieved by different 
studies differ. They can differ from two (BABAKUS; BOLLER, 1992) to eight (CARMAN, 1990) dimensions.

SERVPERF is based on the SERVQUAL instrument, but uses only the SERVQUAL items that assess perceptions. Cronin and Taylor (1992) consider that the 22 evaluation items and the five dimensions of quality proposed by Parasuraman and collaborators (PARASURAMAN; ZEITHAML; BERRY, 1988; ZEITHAML; PARASURAMAN; BERRY, 1990) are very well grounded and they tested them for use in the SERVPERF instrument, and concluded that SERVPERF is more sensitive than SERVQUAL in describing the variations in quality, and also more effective in the operationalization of the quality of service.

The SERVPERF scale is more efficient at reducing the number of items to be measured and in many studies is able empirically to explain greater variance in the overall service quality (JANE; GUPTA, 2004). Many works endorse the superior adequacy of SERVPERF to assess quality of services (BABAKUS; BOLLER, 1992; BOLTON; DREW, 1991a; BOULDING; KALRA; STAELIN; ZEITHAML, 1993; CRONIN; TAYLOR, 1994; LEE; LEE; YOO, 2000; TEAS, 1993). Cronin and Taylor (1994) state that SERVQUAL seems to lack empirical and conceptual support, and that SERVPERF provides a reliable and valid scale to measure service quality levels.

Using data on consumers in fast food restaurants in India, Jain and Gupta (2004) found, for the SERVPERF scale, superior convergent and discriminant validity but less diagnostic power to identify areas for managerial interventions. Fogarty, Catts and Forlin (2000) conducted, in an Australian setting, a validation study employing four different datasets, and a shortened version of the SERVPERF scale. They found that to a very great extent there were overlaps between some of the factors, a result that is similar to other studies, and they gave as one possible reason that the dimensions vary from one industry to another. But they also gave a new explanation: they performed a Rasch analysis, and there was also evidence that the items were too easy to rate highly, so more items that were more difficult to rate highly should be added to the scale (FOGARTY; CATTS; FORLIN, 2000).

These two instruments were applied in different contexts, implying in several cases modified scales to capture specific context elements (BABAKUS; BOLLER, 1992; DABHOLKAR; SHEPHER; THORPE, 2000). In general, the authors accept the necessity to modify scale items to suit the study context (CARRILLAT; JARAMILLO; MULKI, Carrillat, 2007). Diamantopoulos et al (2006) found that international differences in response styles generate item bias.

As almost all the researches attempt to compare the SERVQUAL and SERVPERF scales, relying on only one or two samples, the conclusions are not robust and prevent testing of the impact of contingency factors such as country, language, or industry (CARRILLAT; JARAMILLO; 
MULKI, 2007). A meta-analysis study on the strength of the relationship of service quality and the overall service quality measured by SERVPERF or SERVQUAL, supported by 17 empirical studies over 17 years and 42 effect sizes, was conducted across the five continents by Carrillat et al (2007). They found that the differences between the predictive validity of SERVPERF and SERVQUAL are not significant and that the predictive validity of SERVQUAL increases for context-adapted versions, while the predictive validity of versions of SERVPERF adapted to the study context does not change when compared to the non-modified versions. They also found no support for the statements that the predictive validity of both scales decreases as the degree of individualism of the country decreases, and increases when the scales are administered in the English language.

In the SERVQUAL instrument, the quality of each dimension is achieved by computing the differences between perceptions and expectations of performance, using the following equation for each dimension $k$ :

$$
[\text { SERVQUAL QS }]_{k}=\frac{1}{n_{k}} \sum_{i=1}^{n_{k}}\left(D_{i k}-E_{i k}\right), \quad k=1, \ldots, 5
$$

where:

$Q S=$ quality of service

$D_{i k}=$ perception of item $i$ of dimension $k$

$E_{i k}=$ expectation of item $i$ of dimension $k$

$n_{k}=$ total number of items for dimension $k$

In the SERVPERF instrument the quality, for each dimension, is measured by the simpler equation:

$$
[\text { SERVPERF QS }]_{k}=\frac{1}{n_{k}} \sum_{i=1}^{n_{k}} D_{i k}, \quad k=1, \ldots, 5
$$

The five subscales of quality of service from the SERVQUAL and SERVPERF instruments, according to the reviews undertaken by Parasuraman et al (1988) and Zeithaml et al (1990) are:

- Tangibles: Due to the lack of a physical product, customers' evaluations often depend on the appearance of physical facilities, equipment, personnel, and communication materials. Four items assess tangibles. 
- Reliability: this dimension reflects the consistency and reliability that the performance of a company inspires, i.e., the ability to perform the promised service dependably and accurately. Five items assess reliability.

- Responsiveness: this dimension reflects the company's commitment to help customers and to provide its services promptly. Four items assess responsiveness.

- Assurance: competence of the company, knowledge and courtesy of employees and their ability to convey trust and confidence, credibility and security of the service provided. Four items assess assurance.

- Empathy: the individualized attention the company provides its customers, access to the organization's representatives, communication and understanding the customer. Five items assess empathy.

\section{Objectives and methodology}

The objectives of this study (summarized in Figure 1), are as follows:

- Assess the reliability and validity of the SERVQUAL and SERVPERF scales applied to a Portuguese energy company, EDP, by using the same measures for the five quality dimensions suggested by Parasuraman et al (1988) and Cronin and Taylor (1992), identifying the necessity or not to modify the original scales to adapt them to the present settings. Identify the better scale.

- Establish a relationship between customers' satisfaction and quality of service provided, identifying priority areas to act upon and improve.

Figure 1 - Conceptualized framework 


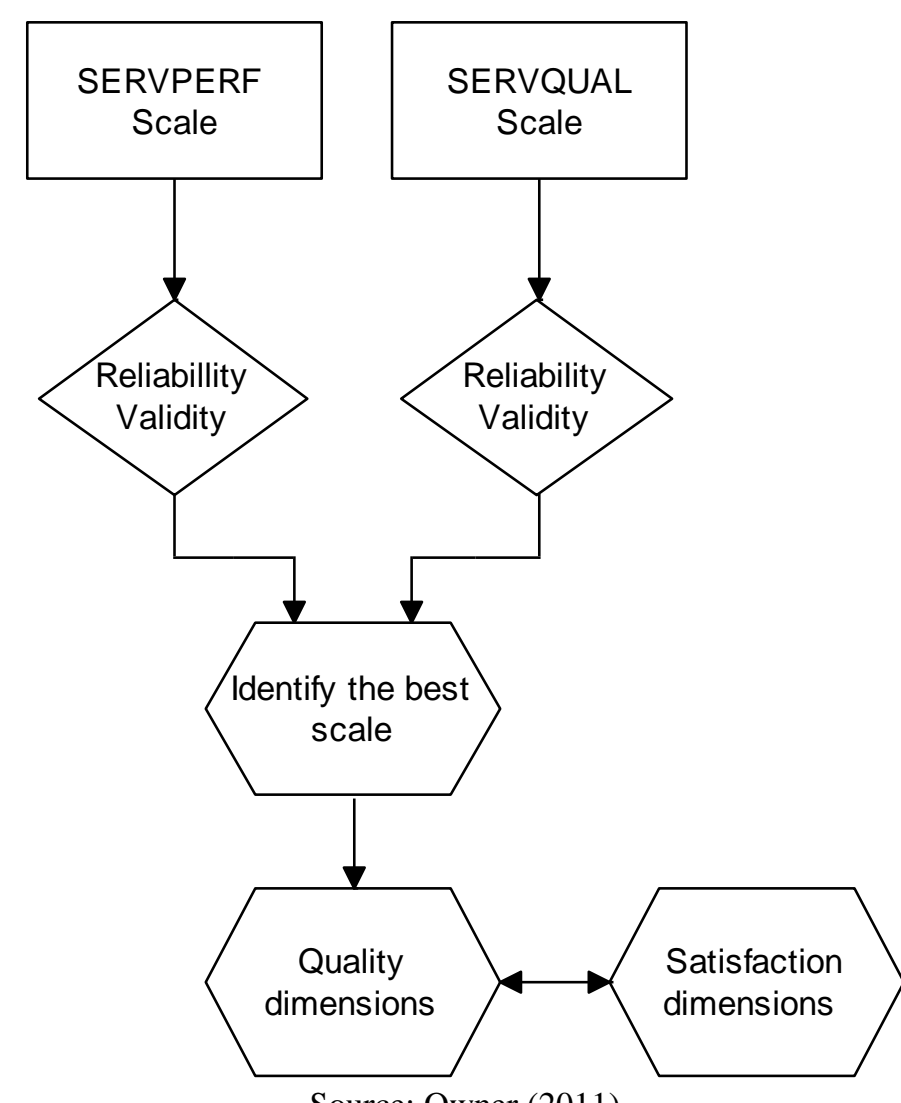

Source: Owner (2011)

To perform the study, the authors applied a questionnaire composed of two parts and an additional question to assess overall satisfaction with the service provided by the company to its residential customers.

The first part of the questionnaire replicates one already conducted by the company with its residential customers to evaluate their perceived satisfaction, measuring the following four dimensions:

Dimension 1 (Quality): Malfunctions and technical quality.

Dimension 2 (Support): Support services in case of malfunctions.

Dimension 3 (Tariffs): Services prices and tariffs.

Dimension 4 (Commercial): Commercial relationship.

The second part seeks to assess the quality of service, consisting of 22 items to assess perceptions and 22 items to assess expectations of residential customers, which are part of the instruments SERVQUAL and SERVPERF, structured on a 7-point Likert scale that ranges from 1 (strongly disagree) to 7 (strongly agree). The subpopulation from the Directorate of North Network and Customers of EDP (DRCN), corresponding to a population of 1.9 million residents and a number of around one million customers (1.037.037 in 2010) was the universe defined geographically. The sampling method was a convenience-type sampling method. The universe defined was divided into homogeneous regions (homogeneous concerning weather conditions, 
social conditions and other issues that can affect electrical supply and quality perception). For each region, subjects were selected by convenience. No compensation was given to the subjects. The questionnaire took place from February 1, 2010 to March 1, 2010, in late winter, when in view of the adverse weather conditions of the previous three months, service quality and customer satisfaction might be compromised, in a universe of 59 counties that make up the DRCN. Replies to the questionnaire were received from 328 customers, $46.3 \%$ women and 53.7\% males, from 20 to 74 years old. The authors used the Statistical Package for Social Sciences (SPSS) software (Statistics 2010), Analysis of Moment Structures (AMOS) (Arbuckle 2007) and LISREL (Jöreskog and Sörbom 2006) to perform the statistical analysis.

\section{Testing the factorial validity of instruments SERVPERF and SERVQUAL}

The SERVPERF and SERVQUAL instruments measure five subscales of quality of service: tangibles, reliability, responsiveness, assurance and empathy (CRONIN; TAYLOR, 1992, 1994; PARASURAMAN; ZEITHAML; BERRY, 1985, 1988) with different conceptualizations of the service quality. SERVPERF measures service quality using a performance-only approach, as opposed to the SERVQUAL instrument, which is a gap-based comparison of the expectations and perceptions of consumers.

In this paper, the non-modified scales for the five quality dimensions suggested by Cronin; Taylor (1992) e Parasuraman; Zeithaml; Berry (1988) were applied to a Portuguese energy company and the validity and reliability of the scales were assessed and compared.

The authors conducted a first-order confirmatory factor analysis (CFA) by using the software AMOS, as a hypothesis-testing approach to data analysis (BYRNE, 2010), to check the validity of those instruments applied to the present study.

The CFA models presented for SERVPERF and SERVQUAL hypothesize a priori that:

- Responses to items can be explained by five factors;

- Each item has a non-zero loading on the factor it is outlined to measure, and zero loadings on all other factors;

- The five factors are intercorrelated;

- The uniqueness terms associated with each observed variable are uncorrelated.

Data yield 253 sample moments, so the number of degrees of freedom is 199. The model is overidentified and ready to be analyzed.

To detect multivariate outliers that could compromise the study, the authors computed the squared Mahalanobis distance for each case, which measures the distance between the scores from 
each case and the sample centroids, in standard deviation units. Ten cases were considered to have values that stood out from the remaining ones, and were eliminated from the analysis.

An important assumption in the conduct of SEM analyses in general is that the data are multivariate normal. This requirement is rooted in large sample theory. Particularly problematic to this kind of analyses are data that are multivariate kurtotic, positive or negative, differing from a multivariate normal distribution (DECARLO, 1997; RAYKOV; MARCOULIDES, 2000). Statistical research shows that whereas skewness tends to impact tests of means, kurtosis severely affects tests of variances and covariances (DECARLO, 1997). The univariate statistics, kurtosis and skew values are not indicative of departure from normality. However, the multivariate kurtosis value suggests that data do not follow a multivariate normal distribution. Hence, interpretations based on the usual ML estimation may be problematic. One way of dealing with the absence of multivariate normality is to use a process called bootstrap resampling (WEST; FINCH; CURRAN, 1995; YUNG; BENTLER, 1996; ZHU, 1997), analysis set out in this study with AMOS software. The results obtained by bootstrap, support and validate the analysis made based on ML estimation.

The evaluation of the extent to which the instrument tested adequately describes the sample data, must be based on several criteria that assess model fit. In particular, the adequacy of the parameter estimates must be evaluated. The authors checked that the maximum likelihood estimates were appropriate and show the magnitude and sign consistent with the theory; the standard errors of the estimates have low values pointing to accurate estimates; and the critical ratios (value of the test statistic $\mathrm{z}$, divided by its estimated standard error) show that all estimates are significantly different from zero to a significance level of 0.001 , hence all parameters are important for the model. The standard errors estimated by bootstrap simulation also have low values and, compared with those obtained initially, there are no large discrepancies. Also, the residuals and the standardized ones were small, pointing to a fairly well fitted model, and the factor loadings are substantial, supporting the validity of the measures.

To assess the adjustment, goodness-of-fit statistics were calculated, which are indicators of a good or poor adjustment of the model to the sample data. There are several goodness-of-fit statistics, three of which are being presented here as indicators of a good fit of the model (Bentler 1990): RMSEA (root mean square error of approximation), CFI (Comparative Fit Index) and RMR (Root Mean Square Residual). The values obtained are presented in Table 1, together with the values obtained by using the LISREL approach for ordinal data (use of polychoric correlations and the diagonally weighted least squares, DWLS, as the estimation method).

From the above, the authors conclude that the data satisfactorily confirms the factor structure for the perception of EDP's performance by their residential customers.

Table 1 - Goodness-of-fit statistics for the SERVPERF instrument 


\begin{tabular}{c|c|c|c|c}
\hline & RMSEA & CFI & RMR & St. $\boldsymbol{R M R}$ \\
\hline ML Estimation & 0.090 & 0.934 & 0.036 & 0.041 \\
\hline DWLS Estimation & 0.063 & 0.993 & 0.036 & 0.036 \\
\hline
\end{tabular}

Source: Owner (2011)

For the SERVQUAL model, the results obtained are less satisfactory. For the sake of comparison, the same goodness-of-fit statistics are presented in Table 2.

Table 2 - Goodness-of-fit statistics for the SERVQUAL instrument

\begin{tabular}{c|c|c|c|c}
\hline & $\boldsymbol{R M S E A}$ & $\boldsymbol{C F I}$ & $\boldsymbol{R M R}$ & St. $\boldsymbol{R M R}$ \\
\hline ML Estimation & 0.105 & 0.911 & 0.070 & 0.042 \\
\hline DWLS Estimation & 0.075 & 0.988 & 0.041 & 0.041 \\
\hline
\end{tabular}

Source: Owner (2011)

Cronbach's alpha coefficients certify the reliability of the dimensions for both instruments. The values are excellent and are displayed in Tables 3 and 4.

Table 3 - Cronbach's alpha (SERVPERF)

\begin{tabular}{c|c|c|c|c}
\hline Tangibles & Reliability & Responsiveness & Assurance & Empathy \\
\hline 0.938 & 0.936 & 0.927 & 0.917 & 0.942 \\
\hline \multicolumn{5}{l}{ Source: Owner (2011) }
\end{tabular}

Table 4 - Cronbach's alpha (SERVQUAL)

\begin{tabular}{c|c|c|c|c}
\hline Tangibles & Reliability & Responsiveness & Assurance & Emphaty \\
\hline 0.939 & 0.934 & 0.912 & 0.925 & 0.941 \\
\hline
\end{tabular}

For each of the instruments, the adjusted determination coefficient (adjusted R Square) between those five dimensions and the overall satisfaction with the service provided by the company, was estimated. This coefficient measures the correlation between the overall satisfaction predicted by a linear regression on the five quality dimensions and the overall satisfaction measured by a single question. The values achieved were 34.0\% for SERVPERF and 5.7\% for SERVQUAL (Tables 5 and 6). These values point to the superior ability of SERVPERF scale to explain the variation in the overall service satisfaction. Also, in the multiple regression analysis performed, it was found for SERVPERF $(F=32.16, p<0.001)$ that only the dimensions 'responsiveness' and 'empathy' were significant determinants of overall satisfaction (for a significance level of 5\%), while only 'responsiveness' revealed statistical significance for the SERVQUAL model $(F=4.63, p$ $<0.001)$. Hence, in predictive validity, SERVPERF shows an advantage over SERVQUAL.

Table 5 - Regression on SERVPERF dimensions

\begin{tabular}{c|c|c|c}
\hline $\boldsymbol{R}$ & $\boldsymbol{R}$ Square & Adjusted $\boldsymbol{R}$ Square & Standard Error \\
\hline 0.593 & 0.351 & 0.340 & 0.673 \\
\hline \multicolumn{4}{l}{ Source: Owner (2011) }
\end{tabular}

Table 6 - Regression on SERVQUAL dimensions

\begin{tabular}{l|c|c|c}
\hline $\boldsymbol{R}$ & $\boldsymbol{R}$ Square & Adjusted R Square & Standard Error \\
\hline
\end{tabular}




\begin{tabular}{l|l|l|l}
\hline 0.269 & 0.072 & 0.057 & 0.804 \\
\hline
\end{tabular}

Source: Owner (2011)

The above results, together with the results achieved by SERVPERF in the confirmatory factor analysis performed, suggest stronger statistical support for convergent and predictive validity for the SERVPERF model compared to SERVQUAL. Hence, the SERVPERF model, in this case, is the one that better explains the quality of the service provided by EDP to their residential customers. Recalling that the scales were not modified, this testifies to the adequacy of SERVPERF to measure the quality of service. These results confirm previous research, but the validation and the superior adequacy of the SERVPERF instrument using the same measures suggested by Parasuraman et al $(1985,1988)$ and Cronin and Taylor (1992), extend the line of research to a novel culture context and settings. Therefore, this was the instrument selected to measure the quality of service.

\section{Customer satisfaction and quality of service}

The next question addressed is how one can relate customer satisfaction (related to the type of service under study), with quality of service dimensions (regardless of the type of service in question), so managers can identify priority areas of service to act upon and improve customers' satisfaction. In literature, one finds disagreement concerning the causality relation between quality and satisfaction. There are researchers who claim that customer satisfaction is an antecedent of the quality of service (BOLTON; DREW, 1991b), whereas others argue that quality of service leads to customer satisfaction (BITNER, 1990; CRONIN; TAYLOR, 1992). Others suggest that quality and satisfaction are determined by the same attributes (BOWERS; SWAN; KOEHLER, 1994). The aim here is to study and explore the interrelationships between quality of service and satisfaction, without the concern of the dependency relationship. To evaluate and analyze the relationship between customer satisfaction and quality of service, the authors rely on the two sets of constructs, the first one composed of the five dimensions of quality (the five dimensions given by SERVPERF) and the second one composed of the four dimensions measuring customer satisfaction. To this purpose, the authors conduct a canonical correlation (BLACK; BABIN; ANDERSON, 2010; HAIR; DILLON; GOLDSTEIN, 1984; TABACHNICK; FIDELL, 2007) between the two sets of dimensions using SPSS. The goal of the analysis is to explain and uncover the dimensions, if any, which relate certain quality constructs to certain satisfaction characteristics.

The first canonical correlation obtained is equal to 0.658 , indicating $43.3 \%$ of overlapping variance between the first pair of canonical variates, while the second is equal to 0.233 , indicating $5.4 \%$ of overlapping variance between the second pair of canonical variates. The remaining two canonical correlations present two low magnitudes $(0.132$ and 0.065$)$. The p-values of the chi- 
square test show that with all four canonical correlations included, $p<0.001$, and with the first canonical correlation removed, $p<0.028$. Subsequent tests are not statistically significant $(p<$ 0.375 and $p<0.533$ ). Therefore, the first pair of canonical variates is highly significant and the second pair is statistically moderately significant. Also, there are no obvious departures from linearity between the first and second pair of canonical variates. The results for the first and second pair of canonical variates are shown in Table 7.

Table 7 - The first two canonical variates

\begin{tabular}{|c|c|c|c|c|}
\hline & \multicolumn{2}{|c|}{ 1st Canonical Variate } & \multicolumn{2}{|c|}{ 2nd Canonical Variate } \\
\hline & Loadings & Cross-loadings & Loadings & Cross-loadings \\
\hline \multicolumn{5}{|l|}{ Quality set } \\
\hline Assurance & 0.916 & 0.603 & -0.232 & -0.054 \\
\hline Tangibles & 0.727 & 0.478 & -0.483 & -0.113 \\
\hline Responsiveness & 0.970 & 0.638 & 0.065 & 0.015 \\
\hline Reliability & 0.879 & 0.578 & 0.124 & 0.029 \\
\hline Empathy & 0.885 & 0.582 & 0.203 & 0.047 \\
\hline$\%$ of variance & 0.772 & & 0.070 & Total $=0.842$ \\
\hline Redundancy & 0.335 & & 0.004 & Total $=0.339$ \\
\hline \multicolumn{5}{|l|}{ Satisfaction set } \\
\hline Malfunctions & 0.909 & 0.598 & -0.126 & -0.029 \\
\hline Commercial & 0.901 & 0.593 & 0.420 & 0.098 \\
\hline Tariffs & 0.836 & 0.550 & -0.259 & -0.060 \\
\hline Support & 0.836 & 0.550 & 0.122 & 0.029 \\
\hline$\%$ of variance & 0.759 & & 0.069 & Total $=0.828$ \\
\hline Redundancy & 0.329 & & 0.004 & Total $=0.333$ \\
\hline Canonical correlation & 0.658 & & 0.233 & \\
\hline
\end{tabular}

Source: Owner (2011)

Total percentage of variance reveals the variance that each canonical variate extracts from the variables on its own side. Hence, the first canonical variate extracts $77.2 \%$ of the variance in quality perception and the second canonical variate extracts $7.0 \%$ of the variance in quality perception. Together they extract $84.2 \%$ of the variance in quality of service. Likewise, the first canonical variate extracts $75.9 \%$ of the variance in customer satisfaction and the second canonical variate extracts only $6.9 \%$ of the variance in customer satisfaction. Together they extract $82.8 \%$ of the variance in customer satisfaction.

The Stewart-Love redundancy index (STEWART; LOVE, 1968) indicates the proportion of variance that the canonical variates from one set of variables extracts from the opposite set of variables, being a measure analogous to the determination coefficient statistic from multiple regression, measuring the ability of a set of variables to explain the variation in the other set. From Table 7, the first canonical variate from the satisfaction set extracts $33.5 \%$ of the variance in quality, and the second canonical variate from the satisfaction set extracts $0.4 \%$ of the variance in quality. Together they extract $33.9 \%$ of the variance in quality. The first canonical variate from the quality set extracts $32.9 \%$ of the variance in satisfaction and the second canonical variate from the 
quality set extracts $0.4 \%$ of the variance in satisfaction. Together they extract $33.3 \%$ of the variance in satisfaction.

The values found for total proportion and redundancy indicate that each of the first pair of the canonical variates is related to the variables of its own side and opposite side, but the second pair is very minimally related, hence interpretation of the second pair of canonical correlation, although significant to a significance level of $0.05(p<0.028)$, is not reliable.

Weights and canonical loadings may be subject to considerable variability from one sample to another, so cross-loadings have been suggested as an alternative to canonical loadings to interpret canonical variates (DILLON e GOLDSTEIN, 1984). Cross-loadings correlate each of the variables directly with the canonical variate from the opposite side. Table 8 shows canonical loadings and cross-loadings. In this case, the interpretations using canonical loadings and cross-loadings are similar. All the quality variables are highly correlated with the first pair of canonical variates (the tangibles being the ones that are less correlated) and the same happens with the satisfaction variables with high loadings. This reveals that all of the quality of service attributes are correlated to all of the satisfaction attributes. All the quality of service attributes, with slightly less importance for tangibles, are important to achieve high customer satisfaction with EDP. The path diagram showing the canonical loadings, and the first canonical correlation for the first pair of canonical variates are shown in Figure 2.

Figure 2 - Loadings and canonical correlation for the first pair of canonical variates

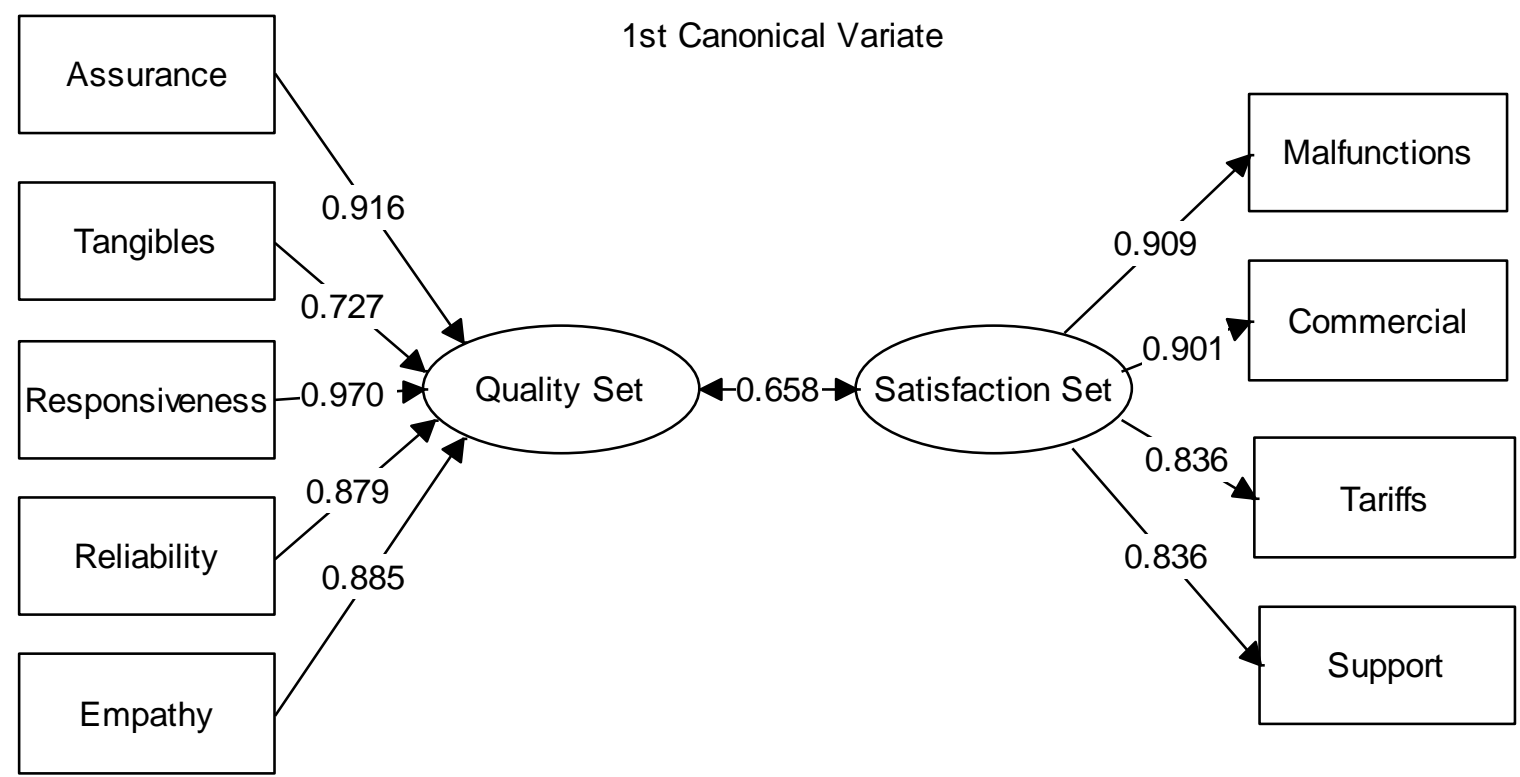

Source: Owner (2011)

To ensure that the results are not only specific to the sample data but can be generalized to the population, a validation of the canonical correlation analyses has also been performed through a sensitivity analysis, consisting of checking whether the loadings change when a variable of one set 
is deleted (HAIR et al, 2010). The canonical loadings and cross-loadings showed great stability and consistency in cases where a variable from one set was deleted. The overall canonical correlation, proportion of variance and redundancy also remained stable. The results where a variable from the quality set has been deleted are shown in Table 8 .

Table 8 - Sensitivity analysis to the removal of one variable of the quality set

\begin{tabular}{|c|c|c|c|c|c|c|}
\hline & \multicolumn{6}{|c|}{ 1st Canonical Variate } \\
\hline Canonical loadings & Original & \multicolumn{5}{|c|}{ Deletion of one variable } \\
\hline \multicolumn{7}{|l|}{ Quality set } \\
\hline Assurance & 0.916 & no & 0.916 & 0.946 & 0.917 & 0.922 \\
\hline Tangibles & 0.727 & 0.727 & no & 0.755 & 0.728 & 0.733 \\
\hline Responsiveness & 0.970 & 0.975 & 0.971 & no & 0.970 & 0.975 \\
\hline Reliability & 0.879 & 0.884 & 0.880 & 0.906 & no & 0.882 \\
\hline Empathy & 0.885 & 0.891 & 0.886 & 0.914 & 0.885 & no \\
\hline$\%$ of variance & 0.772 & 0.763 & 0.835 & 0.780 & 0.773 & 0.779 \\
\hline Redundancy & 0.335 & 0.327 & 0.361 & 0.317 & 0.335 & 0.334 \\
\hline \multicolumn{7}{|l|}{ Satisfaction set } \\
\hline Malfunctions & 0.909 & 0.903 & 0.909 & 0.898 & 0.910 & 0.917 \\
\hline Commercial & 0.901 & 0.910 & 0.901 & 0.897 & 0.900 & 0.891 \\
\hline Tariffs & 0.836 & 0.834 & 0.836 & 0.854 & 0.837 & 0.835 \\
\hline Support & 0.836 & 0.840 & 0.836 & 0.818 & 0.835 & 0.838 \\
\hline$\%$ of variance & 0.759 & 0.761 & 0.759 & 0.752 & 0.759 & 0.758 \\
\hline Redundancy & 0.329 & 0.327 & 0.329 & 0.306 & 0.328 & 0.325 \\
\hline Canonical correlation & 0.658 & 0.655 & 0.658 & 0.638 & 0.658 & 0.655 \\
\hline
\end{tabular}

Source: Owner (2011)

\section{Conclusions and managerial implications}

The success of electricity companies depends on customers' choices. Hence, identifying flaws in quality of service and in customer satisfaction is of fundamental importance to a company to enable it to make efforts to correct and improve the worst aspects, so that it can remain competitive, since its rentability and survival depends on it. In this paper, the authors assess and compare two well-known instruments to measure quality of service, SERVPERF and SERVQUAL, applied to the present context of a Portuguese energy company.

A review of the literature point to SERVQUAL and SERVPERF as being the service quality scales most widely applied, but it is not yet clear which is the best to measure quality of service. Several results from other studies suggest different scale items for each dimension for service quality measured by SERVQUAL and SERVPERF. These differences occur from one service or industry to another and from one country to another. Different individual dimensions have to be considered when studying different cases. This paper presents empirical support suggesting that the service quality in the Portuguese energy context, measured by the performance-based scale, SERVPERF, with the original five dimensions as defined by Cronin and Taylor (1992), is a better instrument than the SERVQUAL scale as defined by Parasuraman et al (1985, 1988). As one important conclusion of this work, the SERVPERF scale reveals better convergent and predictive 
validity than SERVQUAL, when applied to the present Portuguese context of an energy company. This result is achieved without any modification of the scales, with the five constructs and the same items associated as in the works of Parasuraman et al $(1985,1988)$ and Cronin and Taylor (1992). Although this is not a new finding, since it confirms previous research, in this paper the validation of the SERVPERF instrument by using the same measures suggested by Parasuraman et al (1985, 1988) and Cronin and Taylor (1992) extends the line of research to a Portuguese energy settings.

Concerning the relation of service quality with consumer satisfaction, an important issue with strong managerial impact, a relationship between customer satisfaction and the quality of service provided is established. No prior statement has been made on the issue of whether service quality is an antecedent of consumer satisfaction or vice versa. Managers need to improve customer satisfaction using strategies centering on both service quality and satisfaction attributes. SERVPERF is shown to be a good instrument to support managers in taking decisions regarding the present settings.

This analysis also reveals that all of the quality of service attributes were almost equally correlated to all of the satisfaction attributes, with a lower weight concerning tangibles (appearance of physical facilities, equipment, personnel, and communication materials). Hence, to improve customer satisfaction with EDP, all of the quality of service attributes, except, perhaps, the tangibles, that seem to have less importance to residential customers, have almost the same weight.

\section{Resumo}

Este artigo estima a validade e a fiabilidade de dois instrumentos que medem a qualidade de serviço, SERVPERF e SERVQUAL, aplicados a um novo ambiente cultural, uma companhia portuguesa de energia. Para fornecer informações e estratégias visando a atividade de gestão, é estabelecida uma relação entre satisfação e qualidade de serviço. O estudo empírico sugere uma superior validade convergente e preditiva do instrument SERVPERF para medir a qualidade de serviço em comparação com o instrumento SERVQUAL. A principal diferença deste estudo relativamente a outros efetuados, é que este se apoia numa análise fatorial confirmatória, a validação dos instrumentos é efetuada usando as mesmas medidas sugeridas pelos seus criadores e estende a linha de investigação para uma ambiente cultural novo, uma companhia portuguesa de energia. No que diz respeito à relação entre qualidade de serviço e satisfação dos clientes, todas os atributos de qualidade correlacionam de forma idêntica com as dimensões de satisfação, com um menor peso no que se refere aos tangíveis.

Palavras-chave: qualidade; servperf; servqual; análise fatorial confirmatória; correlação canónica.

\section{References}

AHUJA, D.; TATSUTANI, M. Sustainable energy for developing countries, SAPIENS, 2(1). Online since 27 November 2009. URL: http://sapiens.revues.org/823. Access 20 September 2011.

ARBUCKLE, J. L. Amos 18 User's Guide. Chicago: SPSS, 2007. 
ASUBONTENG, P.; McCLEARY, K. J.; SWAN, J. E. SERVQUAL revisited: a critical review of service quality. Journal of Services Marketing, v. 10, n. 6, 62-81, 1996. cross ref

BABAKUS, E.; BOLLER, G. W. An empirical assessment of the SERVQUAL scale. Journal of Business Research, v. 24, 253-268, 1992. crossref

BABAKUS, E.. Measuring service quality in the public utilities: The case of electric, gas and water services. Journal of Nonprofit \& Public Sector Marketing, v. 1, n. 1, 33-49, 1993. crossref

BENTLER, P. M. Comparative fit indexes in structural models. Psychological Bulletin, v. 107, 238-246, 1990. crossref

BITNER, M. J. Evaluating service encounters: the effects of physical surroundings and employee responses. Journal of Marketing, v. 54, n. 4, 69-82. 1990. cross ref

BOLTON, R. N.; DREW, J. H. A Longitudinal Analysis of the Impact of Service Changes on Customer Attitudes. Journal of Marketing, v. 55, 1-9. 1991a. cross ref

BOLTON, R. N.; DREW, J. H. A multistage model of customers' assessment of service quality and value. Journal of Consumer Research, v. 17, 375-384, 1991b. crossref

BOULDING, W.; KALRA, A.; STAELIN, R.; ZEITHAML, V. A. A Dynamic Process Model of Service Quality: From Expectations to Behavioral Intentions. Journal of Marketing Research, v. 30, 7-27, 1993. cross ref

BOWERSs, M. R.; SWAN, J. E.; KOEHLER, W. F. What attributes determine quality and satisfaction with health care delivery?. Health Care Management Review, v. 19, 49-55, 1994. crossref

BROWN, T. J.; CHURCHILL Jr., G. A.; PETER, J. P. Improving the measurement of service quality. Journal of Retailing, v. 69, n. 1, 127-139, 1993. crossref

BUTTLE, F. SERVQUAL: review, critique, research agenda. European Journal of Marketing, v. 30, n. 1, 8-32, 1996. crossref

BYRNE, B. M. Structural Equation Modeling with AMOS. Basic Concepts, Applications, and Programming. In Multivariate Applications Series. Taylor and Francis Group, LLC, 2010.

CARMAN, J. M. Consumer perceptions of service quality: An assessment of the SERVQUAL dimensions. Journal of Retailing, v. 66, 33-55, 1990.

CARRILLAT, F. A.; JARAMILLO, F.; MULKI, J. P. The validity of the SERVQUAL and SERVPERF scales. International Journal of Service Industry Management, v. 18, n. 5, 472-490, 2007. crossref

CLOW, E. K.; VORHIES, D. W. Building a competitive advantage for service firms. Journal of Services Marketing, v. 7, n. 1, 22-32, 1993. cross ref

COLLART, D. Customer relationship management. New York: Pricewaterhouse Coopers, 2000.

CRONIN, J. J.; TAYLOR, S. A. Measuring service quality: A re-examination and extension. Journal of Marketing, v. 56, n. 3, 55-68, 1992. crossref

CRONIN, J. J.; TAYLOR, S. A. SERVQUAL VS SERVPREF: Reconciling performance based and perception-minusexpectations. Journal of Marketing, v. 58, 125-131, 1994. crossref

DABHOLKAR, P. A.; SHEPHERD, C. D.; THORPE, D. I. A comprehensive framework for service quality: an investigation of critical conceptual and measurement issues through a longitudinal study. Journal of Retailing, v. 76, $\mathrm{n}$. 2, 139-173, 2000. crossref

DeCARLO, L. T. On the meaning and use of kurtosis. Psychological Methods, v. 2, 292-307, 1997. crossref

DIAMANTOPOULOS, A.; REYNOLDS, N. L.; SIMINTIRAS, A. C. The impact of response styles on the stability of cross-national comparisons. Journal of Business Research, v. 59, n. 8, 925-935, 2006. crossref 
DILLON, W. R.; GOLDSTEIN, M. Multivariate Analysis: Methods and Applications. New York: Wiley, 1984.

FOGARTY, G. J.; CATTS, R.; FORLIN, C. Identifying shortcomings in the measurement of service quality. Journal of Outcome Measurement, v. 4, n. 1, 425-447, 2000.

GRÖNROOS, C. A service quality model and its marketing implications. European Journal of Marketing, v. 18, n. 4, 36-44, 1984. crossref

HAIR, J. F.; BLACK, W. C.; BABIN, B. J.; ANDERSON, R. E. Multivariate Data Analysis, Pearson Prentice Hall, 2010.

HOFFMAN, K. D.; BATESON, J. E. G. Essentials of Services Marketing: Concepts, Strategies \& Cases, Thomson/South-Western, 2006.

JAIN, S. K.; GUPTA, G. Measuring Service Quality: SERQUAL vs SERPERF Scales. Vikalpa, v. 29, n. 2, 25-37, 2004.

JÖRESKOG, K. G.; SÖRBOM, D. LISREL 8.8. Scientific Software International, Inc, 2006.

LAM, S. K.; WOO, K. Measuring service quality: A test-retest reliability investigation of SERVQUAL. Journal of Marketing Research Society, v. 39, n. 2, 381-396, 1997.

LADHARI, R. Review of Twenty Years of SERVQUAL Research. International Journal of Quality and Service Sciences, v. 1,n. 2, 172-198, 2009. crossref

LEE, H.; LEE, Y.; YOO, D. The determinants of perceived service quality and its relationships with satisfaction. Journal of Services Marketing, v. 14,n. 3, 217-231, 2000. crossref

MEHTA, S. C.; LALWANI, A. K.; HAN, S. L. Service quality in retailing: relative efficiency of alternative measurement scales for different product service environments. International Journal of Retail \& Distribution Management, v. 28,n. 2, 62-72, 2000. cross ref

O'CONNOR, B. P. SPSS and SAS programs for determining the number of components using parallel analysis and Velicer's MAP test. Behavior Research Methods, Instrumentation, and Computers, v. 32, 396-402, 2000. crossref

OLIVER, R. L. Effect of expectations and disconfirmation on postexposure product evaluations: An alternative interpretation. Journal of Applied Psychology, v. 62, n. 4, 480-486, 1977.

OLIVER, R. L. A cognitive model of the antecedents and consequences of satisfaction decisions. Journal of Marketing Research, v. 17, n. 4, 460-469, 1980. crossref

OLIVER, R. L. Measurement and evaluation of satisfaction processes in retailing settings. Journal of Retailing, v. 57,n. 3, 25-48, 198, 1981.

PARASURAMAN, A.; ZEITHAML, V. A.; BERRY, L. A conceptual model of service quality and its implications for future research. Journal of Marketing, v. 49, 41-50, 1985. cross ref

PARASURAMAN, A.; ZEITHAML, V. A.; BERRY, L. Servqual: A multiple-item scale for measuring consumer perceptions of service quality. Journal of Retailing, v. 64,n. 1, 12-40, 1988.

PARASURAMAN, A.; ZEITHAML, V. A.; BERRY, L. Refinement and reassessment of the SERVQUAL scale. Journal of Retailing, v. 67,n. 4, 420-450, 1991.

PARASURAMAN, A.; ZEITHAML, V. A.; BERRY, L. Reassessment of Expectations as a Comparison Standard in Measuring Service Quality: Implications for Further Research. Journal of Marketing, v. 58, 111-124, 1994. crossref

RAYKOV, T.; MARCOUlIDES, G. A. A First Course in Structural Equation Modeling. Mahwah, NJ: Erlbaum, 2000.

SPRENG, R. A., \& OLSHAVSKY, R. W. A desires congruency model of consumer satisfaction. Journal of Academy of Marketing Science, v. 21,n. 3, 169-177, 1993. crossref 
STATISTICS, IBM SPSS. IBM SPSS Statistics for Windows. Version 19.0.0. SPSS Inc., an IBM Company, http://www.spss.com, 2010.

STEWART, D.; LOVE, W. A general canonical correlation index. Psychological Bulletin, v. 70, 160-163, 1968. crossref

TABACHNICK, B. G.; FIDELL, L. S. Using Multivariate Statistics. Pearson International Edition, 2007.

TEAS, R. K. Expectations, performance evaluation and consumer's perceptions of quality. Journal of Marketing, v. 57,n. 4 18-34, 1993.

VELICER, W. F. Determining the number of components from the matrix of partial correlations. Psychometrika, v. 41, 321-327, 1976. crossref

VELICER, W. F.; JACKSON, D. N. Component analysis versus common factor analysis: some further observations. Multivariate Behavioral Research, v. 25,n. 1, 95-112, 1990.

WAVER, D.; BRICKMAN, P. Expectancy, feedback and disconfirmation as independent factors in outcome satisfaction. Journal of Personality and social Psychology, v. 30, n. 3, 420-428, 1974. crossref

WEST, S. G.; FINCH, J. F.; CURRAN, P. Structural Equation Models with Nonnormal Variables: Problems and Remedies. In R. H. Hoyle (Ed.), Structural equation modeling: Concepts, issues, and applications (pp. 56-75). Thousand Oaks, CA: Sage, 1995.

WESTBROOK, R. A.; NEWMAN, J. W.; TAYLOR, J. R. Satisfaction/dissatisfaction in the purchase decision process. Journal of Marketing, v. 42, n. 4, 54-60, 1978. crossref

YUNG, Y.-F.; BENTLER, P. Bootstrapping Techniques in Analysis of Mean and Covariance Structures. In G. A. Marcoulides \& R. E. Schumacker (Eds.), Advanced structural equation modeling: Issues and techniques (pp. 195-226). Mahwah, NJ: Erlbaum, 1996.

ZEITHAML, V. A.; PARASURAMAN, A.; BERRY, L. Delivering Quality Service. Balancing Customer Perceptions and Expectations. New York: The Free Press, 1990.

ZHU, W. Making bootstrap statistical inferences: A tutorial. Research Quarterly for Exercise and Sport, v. 68, 4455, 1997. crossref

ZWICK, W. R.; VELICER, W. F. Comparison of five rules for determining the number of components to retain.

Psychological Bulletin, v. 99, 432-442, 1986. crossref

\section{Dados dos autores}

Nome completo: Manuel Afonso Machado

Função ou cargo ocupado: Mestre em Gestão das Organizações

Endereço completo para correspondência (bairro, cidade, estado, país e CEP): EDP, Avenida do Sol 18 - 4714-509 Braga, Portugal

Telefones para contato: 936408336

e-mail: manuelafonsomachado@gmail.com

Nome completo: Alexandrino Ribeiro

Departamento: Departamento de Gestão, Escola Superior de Gestão, Campus do IPCA

Endereço completo para correspondência (bairro, cidade, estado, país e CEP): 4750-810 Barcelos, Portugal 
Telefones para contato: Tel.: 253802500

e-mail: aribeiro@ipca.pt

Nome completo: Mário Basto

Departamento: Departamento de Ciências, Escola Superior de Tecnologia, Campus do IPCA

Endereço completo para correspondência (bairro, cidade, estado, país e CEP): 4750-810 Barcelos, Portugal

Telefones para contato: 253802260

e-mail:mbasto@ipca.pt

Submetido em: 27/07/2013

Aceito em: 15/09/2014 